\title{
Extraction and Identification of Cactus Opuntia dillenii Seed Oil and its Added Value for Human Health Benefits
}

\author{
Alya Jameel Ali Alsaad ${ }^{1}$, Ammar B Altemimi ${ }^{1, *}$, Salah Naji Aziz', Naoufal Lakhssassi²
}

Alya Jameel Ali Alsaad', Ammar B Altemimi ${ }^{1 * *}$, Salah Naji Aziz' ${ }^{1}$ Naoufal Lakhssassi ${ }^{2}$

'Department of food science-college of Agriculture-University of Basrah, IRAQ. 2Department of Plant, Soil and Agricultural Systems, Southern Illinois University, Carbondale, IL 62901, USA.

\section{Correspondence}

Ammar B Altemimi

Department of food science-college of Agriculture-University of Basrah, IRAQ

Tel. +9647735640090

E-mail: ammaragr@siu.edu

History

- Submission Date: 29-03-2019;

- Review completed: 08-04-2019;

- Accepted Date: 15-04-2019

\section{DOI : 10.5530/pj.2019.11.92}

Article Available online http://www.phcogj.com/v11/i3

\section{Copyright}

() 2019 Phcogj.Com. This is an openaccess article distributed under the terms of the Creative Commons Attribution 4.0 International license.

\section{ABSTRACT}

Cactus Opuntia dillenii presents multiple health benefits. The current study aims to investigate the seed composition and content of prickly pear fruits from Iraq. Results obtained showed that Opuntia dillenii contained $9.5 \%$ of seeds of the entire fruit while extracted oil presented $6.5 \%$ of total seed composition. Fatty acid analysis revealed that the polyunsaturated linoleic acid $(72.9 \%)$, the saturated palmitic acid $(15.12 \%)$ and stearic acid $(7.51 \%)$ presented the main seed fatty acids of Opuntia dillenii. Other essential oils were detected but at low percentage. Interestingly, stearic acid content in Cactus oil presented $7.51 \%$, which is much higher than soybeans $(\sim 3 \%)$ that are considered as the largest source of animal protein feed and the second largest source of vegetable oil worldwide. Stearic acid presents neutral effects on the concentration of blood serum LDL cholesterol and does not exhibit cholesterolemic effects on human health. The analysis of cactus seed oil demonstrated a strong antioxidant ability estimated by their capability to reduce oxidation. Treated cake with BHT (butylated hydroxytoluene) at concentration of $0.02 \mathrm{mg} / 100 \mathrm{~g}$ of butter from cactus seed-oil exhibited lower peroxide values ranging from 0.67 to 1.5 milli-equivalents (meq) peroxide per $1 \mathrm{~kg}$ of oil throughout 15 days of storage time at $4{ }^{\circ} \mathrm{C}$. In contrast, treated cake with $0.11 \mathrm{mg} / 100 \mathrm{~g}$ of butter from cactus seed-oil presented lower peroxide values ranged from 0.69 to 2.5 meq peroxide per $1 \mathrm{~kg}$ of oil among all treatments. Because of its high-saturated fatty acid composition $(>22 \%)$ and rich linoleic acid $(72.9 \%)$ composition, Opuntia dillenii present an alternative source with several health benefits by lowering cholesterol risks and for biodiesel production.

Key words: fatty acid, cactus, seed-oil, GC-MS, cake, peroxide value.

\section{INTRODUCTION}

Cactus Opuntia dillenii is massively grown in the South of Iraq, especially in Basrah city (Al-Fao). Cactus belongs to the dicotyledonous angiosperm Cactaceae family that includes about 1500 species of cactus worldwide. Due to its acidic taste and the presence of a large number of seeds within the fruit, cactus is not widely used for consumption. However, recent studies have highlighted the presence of multiple benefits for human health and medicine in natural cactus. ${ }^{1,2}$ It has been shown that Opuntia dillenii has anti-inflammatory, analgesic, anti-hyperglycemia, and hypocholesterolemic effects. ${ }^{3,4}$ During the last decade, consumer demand for food with high nutritional value has increased as a result of their high-fat (fatty acids) content, as well as health benefits, which have created a new category known as "functional foods" .5,6 Cactus is rich in minerals with inorganic nutrients including calcium, phosphorus, iron, magnesium, copper, and zinc usually required in small amounts ( 1 to 2500 mg per day). Humans and other vertebrates need large amounts of calcium because it is necessary for bone and for normal function of nerves and muscles. ${ }^{7}$ Adenosine triphosphate (ATP) and acidbase balance does not occur without the presence of phosphorus, which is essential for nucleic acid composition. ${ }^{8}$ In addition, red blood cells cannot function properly without iron in the hemoglobin. Iron is also an important component of the cytochromes that function in the cellular respiration process. $^{7}$ Other minerals like magnesium, copper, and zinc are important cofactors that can be found in the structure of certain enzymes and indispensable in numerous biochemical pathways. ${ }^{9}$

Oil-seed content from O. ficus-indica (prickly pears) ranges from $5.0 \%$ to $14.4 \%$ according to the Turkish varieties Ortaoren or Eskioba Matth"aus. The seeds of Opuntia dillenii were used as high-quality edible oil with health benefits as they contains high amounts of unsaturated fatty acids. The main fatty acids of the 17 cactus oil samples from Morocco are palmitic acid and linoleic acid. ${ }^{10}$ Cactus Pear seedoil contains saturated and unsaturated fatty acids, with higher linoleic acid content, while myristic, palmitoleic, hexa-decadienoic, and margaric are present in minimal amounts. Opuntia dillenii seed-oil also includes phenolic acids, flavonoids, and tannins that are considered as antioxidants for the pharmaceutical industry. ${ }^{11}$ The fatty acid composition of this oil is an essential indicator for its added nutritional value. ${ }^{12}$ Supplementation of bakery products like cake, that present a rich source of energy and protein, with butter of Cactus seed-oil will further help in improving its nutritional value and chemical qualities. Development of value added products from diverse raw ingredients is receiving the prime focus of the food processing industry and by researchers. ${ }^{13,14}$ 
The main objectives of this study were (1) determination of minerals compounds from dry seeds Cactus Opuntia dillenii grown in Basrah city, (2) analyze the extracted seed-oil by GC-MS to determine their fatty acid composition and other essential oils that may be present, (3) explore the feasibility of development of added cake value from essential oils, and (4) determination of the antioxidant activity of Cactus seedoil by measuring the peroxide value of the cake to understand the inhibitory oxidation effect of extracted Cactus seed-oil after storage by refrigeration.

\section{MATERIALS AND METHODS}

\section{Sample collection and preparation}

Mature fruits of prickly pear, Cactus Opuntia dillenii, were collected 6 weeks after blossoming in August 2017 from Ma’Amir, Al-Fao (Basra, Iraq) (Figure 1). The cultivated cactus are grown at Ma'Amir (30.027148 deg latitude, $48.436624 \mathrm{deg}$ altitude and 3 feet elevation), at al-Faw Peninsula in the Persian Gulf, located in the extreme southeast of Iraq, and is part of a delta for the Shatt al-Arab river. Temperatures typically vary from $49^{\circ} \mathrm{F}$ to $109^{\circ} \mathrm{F}$ with very low chance of rain through out the year. type of soil is silt and sand. Cactus seeds were studied during fruit ripening.

Fruits were peeled, and seeds were isolated by pressing the edible pulp. Next, the seeds were washed with distilled water and dried at room temperature to calculate the percentage of seeds in the edible fraction (pulp) by taking the weight of the pulp prior to seed-weight. Seeds were macerated to a fine powder, passed through a sieve with particle size of $0.425 \mathrm{~mm}$ and stored at $-20^{\circ} \mathrm{C}$ until use. ${ }^{9}$

\section{Determination of mineral compounds}

In order to determine the mineral compounds of Opuntia dillenii, $1 \mathrm{~g}$ weight of dry powder seed was placed in silica dish and then in a muffle furnace. Moreover, samples were burned to ash at $550^{\circ} \mathrm{C}$ for $4 \mathrm{~h}$. Next, samples were cooled and ash dissolved in $5 \mathrm{ml}$ of $2 \mathrm{~N} \mathrm{HNO}_{3}$, then filtered and diluted to $50 \mathrm{ml}$ volume in distilled water. The samples were analyzed in three replicates, and mineral compounds were determined for calcium, magnesium, sodium, potassium, iron, phosphorus, copper, and zinc by Atomic Absorption Spectrophotometry (AAS, USA) as previously described. ${ }^{15}$

\section{Essential oil extraction}

The essential oil samples were obtained by hydro distillation for $4 \mathrm{~h}$ and $30 \mathrm{~min}$ in a Clevenger-type apparatus using $50 \mathrm{~g}$ of dried seeds in $1 \mathrm{~L}$ of distilled water, with three technical replicates. After extraction, the essential oil samples were centrifuged at 5,000 rpm for $2 \mathrm{~min}$ to separate the residual water from the oil. To calculate the essential oil yield content, the total mass of the essential oil sample to be analyzed was measured using an analytical balance (accurate to $0.0001 \mathrm{~g}$ ).

\section{Determination of antioxidant activity (scavenging activity of DPPH radical)}

The method was carried out as described previously. ${ }^{16}$ The essential oils were dissolved in methanol at different concentrations $(10,50,100,500$

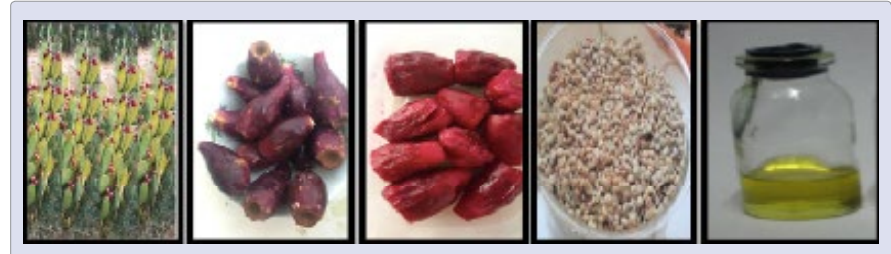

Figure 1. The Different plant tissue tested in the current study. Left to right are cultivated Cactus Opuntia dillenii plant, fresh fruits, dry fruit, seeds, extracted oil. and $1,000 \mu \mathrm{g} / \mathrm{mL}$ ). The assay mixture (total volume of $1 \mathrm{~mL}$ ) contained $500 \mu \mathrm{L}$ of the oil, $125 \mu \mathrm{L}$ prepared DPPH ( $1 \mathrm{mM}$ in methanol) and 375 $\mu \mathrm{L}$ solvent (methanol). After $30 \mathrm{~min}$ incubation at $25^{\circ} \mathrm{C}$, the decrease in absorbance was measured at $\lambda=517 \mathrm{~nm}$. Ascorbic acid was used as comparative sample. The radical scavenging activity was calculated from the equation: \% DPPH $=\mathrm{Abs}_{\text {control }}-\mathrm{Abs}_{\text {sample }} / \mathrm{Abs}_{\text {control }} \times 100$ ((absorbance of control), $\mathrm{Abs}_{\text {sample }}$ (absorbance of sample $\mathrm{Abs}_{\text {control }}$

\section{Preparation of fatty acid methyl esters (FAME)}

Total fatty acid content and fatty acid composition were determined simultaneously in the fruit's seeds-oil samples. Fatty acid analysis was performed in triplicate and consisted of two consecutive steps; (1) preparation of fatty acid methyl ester (FAME) and (2) chromatographic analysis. The AOAC (1996) method was followed to esterify the lipid extract. FAME was prepared from the lipid extracted samples by heating with the methanolic $\mathrm{NaOH}$ and then with $\mathrm{BF} 3$ absolute Methanol for esterification. Next, $5 \mathrm{ml} \mathrm{n}$-heptane was added to recover the methyl esters. organic phase, saturated with $\mathrm{NaCl}$ solution, was added to the mixture, and the aqueous and organic layers were separated using a profile-separating funnel. The upper $n$-heptane phase was pipetted out into $10 \mathrm{ml}$ glass vials and then stored at $-20^{\circ} \mathrm{C}$ until performing GCMS analysis.

\section{Fatty acid methyl ester (FAME) analysis by gas} chromatography mass spectrometer (GC MS)

The gas chromatography analysis of methylated fatty acids was performed on a Shimadzu QP2010 quadrupole Gas Chromatography Mass Spectrometer (GC-MS) instrument equipped with a carbowax (30 m $\times 0.25 \mathrm{~mm} \mathrm{ID;} 0.25$ ( $\mu \mathrm{m}$ film thickness) capillary column (Intercut DB5MS, Japan). One microliter of sample was injected into the capillary column. Helium was used as the carrier gas. Injector and detector temperatures were set at $280^{\circ} \mathrm{C}$. Injection was performed in split mode (1:30). The column temperature was programmed initially at $50{ }^{\circ} \mathrm{C}$ for 1 minute, then to increase at a rate of $5{ }^{\circ} \mathrm{C}$ per min at final temperature of $280^{\circ} \mathrm{C}$. Fatty acid methyl esters were separated at constant pressure $(100 \mathrm{kPa})$ and peaks were identified by comparing the mass spectra with the mass spectral database. The identification of compounds was based on the comparisons of their mass spectra with NIST Library 2008.

\section{Application of cactus seed-oil in cake}

\section{Cakes preparation}

$200 \mathrm{~g}$ of flour, $120 \mathrm{~g}$ of sugar, $100 \mathrm{ml}$ of skimmed milk, $80 \mathrm{~g}$ of fresh whole eggs, $100 \mathrm{~g}$ of butter, $8 \mathrm{~g}$ of baking powder, and $2 \mathrm{~g}$ of vanilla were used. All ingredients were mixed during $10 \mathrm{~min}$ at normal speed using a Kitchen-Aid Professional Mixer. All of the cake ingredients were placed into a metallic mold (100 $\mathrm{mm}$ diameter and $50 \mathrm{~mm}$ height), lightly coated with vegetable corn oil and next baked in an electric oven for 30 $\min$ at $180^{\circ} \mathrm{C}$. Butter was substituted by Cactus seed-oil at $0 \%$ (control), $5 \%, 10 \%$, and $15 \%$. After baking, cakes were removed from the mold and left $30 \mathrm{~min}$ for cooling to room temperature. Then, cake samples were placed on coded white glass plates for the sensory evaluation.

\section{Sensory evaluation of cake}

Evaluation of baked cake quality characteristics was carried out following cooling to room temperature. Sensory evaluation was performed by twenty-specific evaluators from the Department of Food Science at the College of Agriculture at Basrah University. Cakes were randomly assigned to each panelist. A 10-point hedonic scale

score was applied to evaluate important parameters including color, color, texture, taste, odor and overall acceptability. ${ }^{17}$ The designated number 10 was given to "I like it extremely well" while number 1 was given to "I dislike it extremely". 


\section{Peroxide value determination}

The number of peroxide value milli-equivalents (meq) peroxide per $1 \mathrm{~kg}$ of oil was measured as described earlier. ${ }^{18}$ Control and treated cake with different concentrations of seeds oil 0.03, 0.05, 0.07, 0.09, and $0.11 \mathrm{mg} / 100 \mathrm{~g}$ of butter and BHT (butylated hydroxytoluene) at concentration of $0.02 \mathrm{mg} / 100 \mathrm{~g}$ of butter, was stored at different times $0,5,10$, and 15 days at $4{ }^{\circ} \mathrm{C}$. Next, $1 \mathrm{~g}$ of the sample was boiled with 1 g potassium iodide and $20 \mathrm{~mL}$ of solvent mixture (Glacial acetic acid and chloroform $[2: 1] \mathrm{v} / \mathrm{v}$ ) for $30 \mathrm{~s}$ and then vigorously for another $30 \mathrm{~s}$ before being filtrated to collect the leachate. Leachate was next poured into $20 \mathrm{~mL}$ of $5 \%$ potassium iodide and the boiling tube washed twice with $25 \mathrm{~mL}$ of distilled water. Titration was carried out with $0.002 \mathrm{M}$ of the $\mathrm{Na}_{2} \mathrm{~S}_{2} \mathrm{O}_{3}$ using starch indicator. Blank was similarly titrated. Peroxide value determination was calculated as follow:

Peroxide value $=\frac{1000\left(\mathrm{~V}_{2}-\mathrm{V}_{1}\right) \mathrm{T}}{\mathrm{M}}$

Where $\mathrm{M}=$ mass of oil taken $(1 \mathrm{~g}) ; \mathrm{V}_{2}=$ volume of $0.1 \mathrm{~N} \mathrm{Na} 2 \mathrm{~S} 2 \mathrm{O} 3 ; \mathrm{V}_{1}$ $=$ volume of $0.1 \mathrm{~N} \mathrm{Na}_{2} \mathrm{~S}_{2} \mathrm{O}_{3}$ used as blank; and $\mathrm{T}=$ normality of $\mathrm{Na}_{2} \mathrm{~S}_{2} \mathrm{O}_{3}$ $(0.1 \mathrm{~N})$.

\section{Statistical analysis}

Analysis of variance (ANOVA) was carried out using SPSS program (version. 16). The cake characteristics with or without seed oil were analyzed using ANOVA. Means and standard deviation of three replicates were calculated. Analysis of variance (ANOVA) was performed to determine any significant differences $(p<0.05)$.

\section{RESULTS AND DISCUSSION}

\section{Yield percentage of seeds in pulp}

Yield percentage analysis showed that the seeds contained in the pulp of Opuntia dillenii constituted about $9.5 \%$ of the fruit pulp. The obtained seed content was in agreement with those found in the literature, ${ }^{19}$ which ranges between 2 to $10 \%$ of the fruit pulp. Prickly pear seeds presented $10-15 \%$ of the edible pulp and are usually discarded as waste after extraction of the pulp as described by Sáenz. ${ }^{20}$ The edible part of the fruit contains a relatively large number of seeds, which amount can vary from $30 \%$ to $40 \%$ on a dry weight basis. These seeds are usually discarded while proper utilization of these waste products could lead to an important new source of oil and meal. ${ }^{21}$ Prickly pear seeds are $10-15 \%$ of the edible pulp and are usually discarded as waste after extraction of the pulp seeds from Opuntia sp. and were shown to be rich in polyphenols, flavonoids, and tannins. The concentrations of those molecules were shown usually to be higher than in the fruit pulp. ${ }^{22}$

\section{Determination of mineral compounds}

Analysis of the mineral compounds reveals that Cactus fruit seeds are rich in minerals, with a predominance of calcium, phosphorus, and potassium at $280.81,243.90$, and $181.96 \mathrm{mg} / 100 \mathrm{~g}$ respectively, as shown in Table 1. Percentage of magnesium, sodium, and Zinc was 156.94, 28.01 , and $52.90 \mathrm{mg} / 100 \mathrm{~g}$, respectively. Copper and iron contained less amounts with 1.36 and $3.63 \mathrm{mg} / 100 \mathrm{~g}$, respectively. Our results showed that the macro elements contents of Cactus Opuntia dillenii seeds were less than those reported in the literature by Ghazi et al. (2015), where Phosphorus was found to be the major element at $970.15 \mathrm{mg} / 100 \mathrm{~g}$ dry

Table 1: Distribution and content of minerals in Cactus Opuntia dillenii seeds expressed as $\mathbf{m g} / 100 \mathrm{~g}$ dry weight.

\begin{tabular}{|c|c|c|c|c|c|c|c|c|}
\hline \multicolumn{9}{|c|}{ OD Mineral (mg/100 g dry weight) } \\
\hline \multirow[t]{3}{*}{ Minerals } & \multicolumn{5}{|c|}{ Macro elements } & \multicolumn{3}{|c|}{ Trace elements } \\
\hline & $\mathrm{Ca}$ & $\mathrm{Mg}$ & $\mathrm{Na}$ & $\mathrm{K}$ & $\mathrm{P}$ & $\mathrm{Fe}$ & $\mathrm{Cu}$ & $\mathrm{Zn}$ \\
\hline & 280.81 & 156.94 & 28.01 & 181.96 & 243.90 & 3.63 & 1.36 & 52.90 \\
\hline
\end{tabular}

seeds followed by calcium at $408.28 \mathrm{mg} / 100 \mathrm{~g}$, magnesium at 240.30 $\mathrm{mg} / 100 \mathrm{~g}$, potassium at $201.96 \mathrm{mg} / 100 \mathrm{~g}$, and sodium at a lower content $18.18 \mathrm{mg} / 100 \mathrm{~g}$, in Cactus Opuntia dillenii seeds.

\section{Essential oil yield}

The present study shows that yield percentage of extracted oil from Cactus Opuntia dillenii was about $6.5 \%$. Stintzing ${ }^{23}$ reported that seeds are a relatively untapped source of the lipid fraction, presenting 7 to $15 \%$ by weight of the whole seed and is characterized by a high degree of unsaturation, wherein the linoleic acid is the main fatty acid and ranged between $56,1 \%$ to $77 \%$. Labuschagne and $\mathrm{Hugo}^{24}$ reported that oil content in Cactus Opuntia dillenii seeds from South Africa was 5.69 $\%$, while Chang ${ }^{25}$ reported that oil content in Cactus pear seed oil from China was $6.01 \%$. The two results were close to the obtained results from the present study. However, oil content from Italian cultivar was $9.14 \%,{ }^{26}$ and oil content was $11.05 \%$ from another cultivar from Tunisia. ${ }^{9}$ Compared to other oil-seed crops, Opuntia dillenii presented lower oil content. Indeed, higher amounts were recovered from cotton seeds $15-24 \%$, soybean seeds $17-21 \%$, grape seeds $6-20 \%$, and olive $20-25 \% .^{27}$

\section{Antioxidant activity}

The potential antioxidant activity of the oil was determined on the basis of DPPH free radical scavenging activity. The analysis of cactus seed oil demonstrated a strong antioxidant abilities estimated by their capability to reduce oxidation. In addition, the obtained results showed the potent scavenging activity of cactus seed oil compared to the control (ascorbic acid). The obtained DPPH scavenging activities were $36.5-78.1 \%$ and $46.5-81.3 \%$ for cactus seed oil extraction and ascorbic acid at concentrations $(10,50,100,500$, and $1,000 \mu \mathrm{g} / \mathrm{mL}$ ), respectively (Figure 2 ). The statistical analysis results showed that there was no significant difference $(p>0.05)$ between cactus seed oil extraction and ascorbic acid at concentrations 10,50 , and $100 \mu \mathrm{g} / \mathrm{m}$ ) for DPPH scavenging activities. However, there was significant difference $(p<0.05)$ between cactus seed oil extraction and ascorbic acid at concentration at 500 and $1000 \mu \mathrm{g} / \mathrm{mL}$ for DPPH scavenging activities. The scavenging activities increased significantly while increasing the concentration. In fact, cactus seed oil represents a strong electron donor and could react with free radicals to convert them to more stable products and terminate the radical chain reaction. This observed effect could be associated with high content of phenolic components such as Tocopherols, a natural occurring antioxidants presenting biological activity. ${ }^{28}$ The extracted Opuntia stricta oil using supercritical (SC) $-\mathrm{CO}_{2}$ method showed high antioxidant activities due to enriched polyphenols $(172.2 \pm 11.9 \mu$ g gallic acid equivalents (GAE) $\mathrm{g}^{-1}$ oil), a process that led to more compounds. ${ }^{29}$ The cactus seed oil extracts have an important role in treating several diseases including hypoglycemic effects, anti-tumoral, and antioxidant activities. ${ }^{30} \mathrm{DPPH}$ scavenging activities increased significantly with increasing the concentration of the cactus seed oil and fruit juices from 5 to $20 \mu \mathrm{L} / \mathrm{mL}$. It has ranged between $24.84-53.15 \%$ for O. Ficus while O. dillenii values ranged from $21.04-42.6 \%$ and ascorbic acid ranged from 21.02 to $63.85 \% .^{31}$

\section{Analysis of Opuntia dillenii seeds-oil by gas} chromatography-mass spectrometry (GC-MS)

Gas-chromatography coupled with mass spectrometry analysis revealed the presence of an interesting profile of fatty acids contained in extracted seed oil from Opuntia dillenii (Figure 3 and Table 2). The current study reveal that the main fatty acids were 9,12-Octadecadienoic acid methylester (linoleic acid) with $72.9 \%$, Hexadecanoic acid methyl ester (palmitic acid) with $15.12 \%$, and the Octadecanoic acid methyl ester (stearic acid) with $7.51 \%$. Other essential oils were detected but at low percentages, these include the 1,4-Benzenedicarboxylic acid dimethyl ester, Methyl tetradecanoate, 9-Hexadecenoic acid methyl ester, cis- 

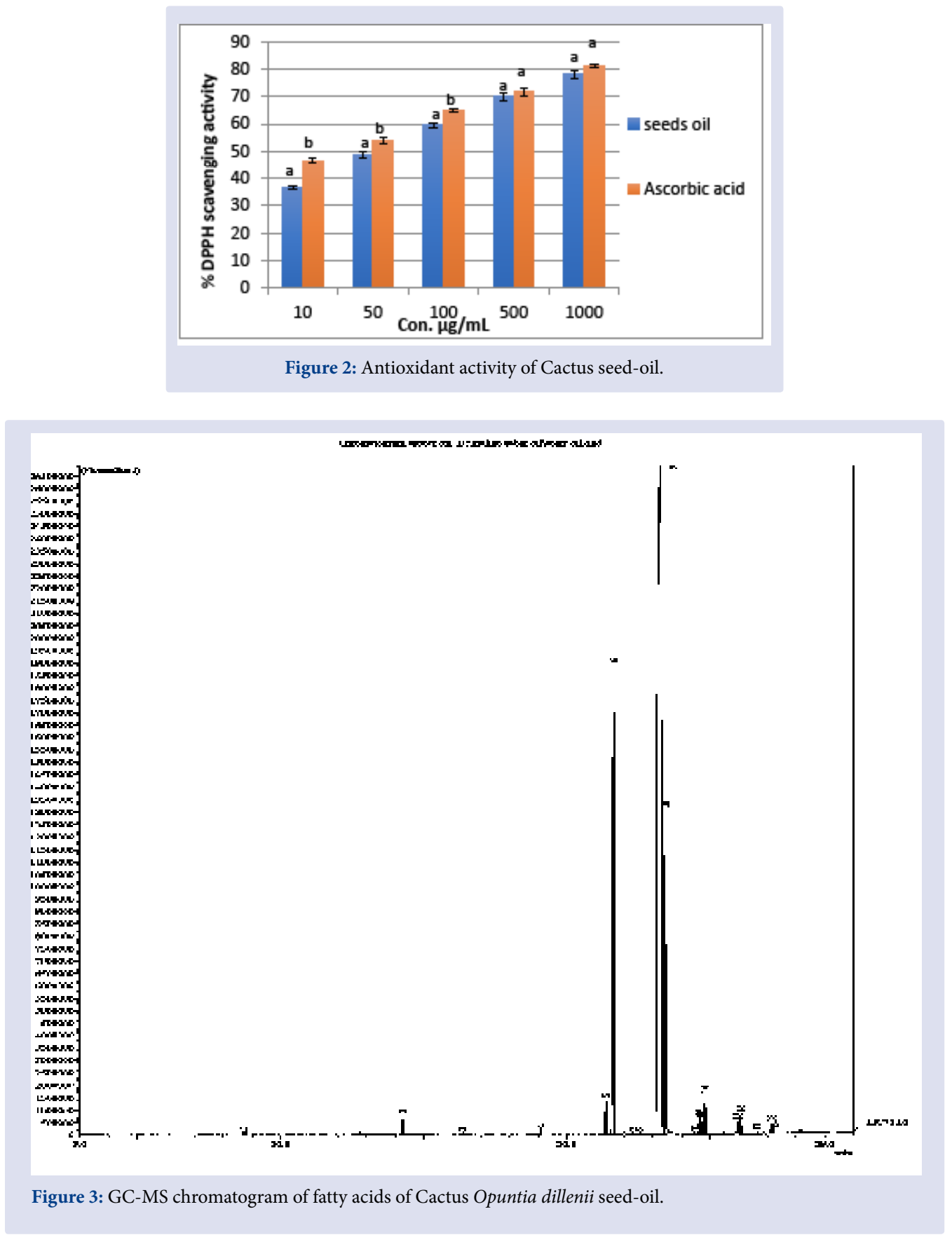

11-Eicosenoic acid methyl ester, cis-13-Eicosenoic acid methyl ester, Methyl 18-methylnonadecanoate, and Methyl 11-docosenoate. The obtained results showed that Cactus Opuntia dillenii seed-oil was rich in fatty acids. The saturated fatty acids identified include palmitic acid (C16:0) and stearic acid (C18:0) with levels containing up to $22.63 \%$ saturated fatty acids, while high levels of the poly-unsaturated omega- 6 linoleic acid (C18:2) exceeding 72.9\% were obtained.

Filip $^{32}$ reported that the level of fatty acids in Opuntia dillenii seed oil is higher than in sunflower seed oil, grape seed oil, or sesames seed oil. Omega-6 like linoleic acid and arachidonic acid present a hypocholesterolemic effect and present important inhibitory properties against colon cancer metastatic cells. ${ }^{33}$ Three types of sunflower seed oil were developed; high-oleic, mid-oleic and low-oleic (FAO). Consequently, the linoleic acid content is high in low oleic germplasms but is low in high oleic sunflower seed oil. Differences between the oil content of cactus seeds from different locations can be explained by differences in growing locations and environmental conditions ${ }^{28}$ Opuntia dillenii seed-oil presents higher proportion of poly-unsaturated fats (linoleic acid) compared to certain conventional edible vegetable oils such as olive oil (3.5 - 21\%), soybean oil (49.7\%), corn oil (47.7\%), sesame oil (44.5\%), sun flower oil (49.7\%), and cotton oil (50.0\%). ${ }^{34-36}$ These characteristics illustrate that Opuntia dillenii may be an interesting natural source of edible oil containing high amounts of healthy fatty acids. The obtained seed-oil contents were in agreement with those found in the literature. ${ }^{37}$ Although poly-unsaturated fatty acids like (linoleic acid) are predominant, many reports have shown that saturated fatty acids (i.e. palmitic and stearic acids) were found in percentages ranging from (16-17\%). These results were in agreement with recently published studies by Ghazi ${ }^{8}$ where the linoleic acid was the dominating fatty acid with an exceptional level up to $79.83 \%$, followed by palmitic acid (13.52\%), and stearic acid $(2.75 \%)$ resulting in $16.27 \%$ saturated fatty acids. The current study shows that Cactus Opuntia dillenii contains similar amounts of linoleic acid levels (72.9\%), but 
Table 2. Fatty acid content identified in Cactus Opuntia dillenii seed-oil.

\begin{tabular}{|c|c|c|c|c|c|c|c|}
\hline $\mathbf{P}$ & R.Tim & Area & Area\% & Name & Formula & MW & $\begin{array}{c}\text { Ret } \\
\text { Index }\end{array}$ \\
\hline 1 & 8.71 & 3466 & 0.09 & Eucalyptol & $\mathrm{C} 10 \mathrm{H} 18 \mathrm{O}$ & 154 & 1059 \\
\hline 2 & 14.26 & 16639 & 0.46 & 3-Cyclohexene1-methanol,.alpha.,.alpha.,4-trimethyl-, acetate & $\mathrm{C} 12 \mathrm{H} 20 \mathrm{O} 2$ & 196 & 1333 \\
\hline 3 & 16.36 & 2600 & 0.07 & 1,4-Benzenedicarboxylic acid, dimethylester & $\mathrm{C} 10 \mathrm{H} 10 \mathrm{O} 4$ & 194 & 1440 \\
\hline 4 & 19.09 & 4946 & 0.14 & Methyltetradecanoate & $\mathrm{C} 15 \mathrm{H} 30 \mathrm{O} 2$ & 242 & 1680 \\
\hline 5 & 21.35 & 35624 & 0.98 & 9-Hexadecenoic acid, methylester,(Z)- & $\mathrm{C} 17 \mathrm{H} 32 \mathrm{O} 2$ & 268 & 1886 \\
\hline 6 & 21.62 & 552445 & 15.12 & Hexadecanoic acid, methylester & $\mathrm{C} 17 \mathrm{H} 32 \mathrm{O} 2$ & 268 & 1886 \\
\hline 7 & 22.32 & 2704 & 0.07 & cis-10-Heptadecenoic acid, methylester & $\mathrm{C} 18 \mathrm{H} 34 \mathrm{O} 2$ & 282 & 1986 \\
\hline 8 & 22.55 & 3303 & 0.09 & Heptadecanoic acid, methylester & $\mathrm{C} 18 \mathrm{H} 36 \mathrm{O} 2$ & 284 & 1978 \\
\hline 9 & 23.24 & 2662843 & 72.90 & 9,12-Octadecadienoic acid(Z,Z)-, methylester & $\mathrm{C} 19 \mathrm{H} 34 \mathrm{O} 2$ & 294 & 2093 \\
\hline 10 & 23.43 & 274318 & 7.51 & Octadecanoic acid, methylester & $\mathrm{C} 19 \mathrm{H} 38 \mathrm{O} 2$ & 298 & 2077 \\
\hline 11 & 24.46 & 2295 & 0.06 & Cyclopropaneoctanoic acid, 2-[[2-[(2- & $\mathrm{C} 22 \mathrm{H} 38 \mathrm{O} 2$ & 334 & 2266 \\
\hline 12 & 24.65 & 19462 & 0.53 & cis-11-Eicosenoic acid, methylester & $\mathrm{C} 21 \mathrm{H} 40 \mathrm{O} 2$ & 324 & 2284 \\
\hline 13 & 24.70 & 10616 & 0.29 & cis-13-Eicosenoic acid, methylester & $\mathrm{C} 21 \mathrm{H} 40 \mathrm{O} 2$ & 324 & 2284 \\
\hline 14 & 24.83 & 27387 & 0.75 & Methyl18-methylnonadecanoate & $\mathrm{C} 21 \mathrm{H} 42 \mathrm{O} 2$ & 326 & 2212 \\
\hline 15 & 25.960 & 7648 & 0.21 & Methyl11-docosenoate & $\mathrm{C} 21 \mathrm{H} 40 \mathrm{O} 2$ & 324 & 2284 \\
\hline 16 & 26.06 & 14292 & 0.39 & Methyl20-methyl-heneicosanoate & $\mathrm{C} 23 \mathrm{H} 46 \mathrm{O} 2$ & 354 & 2411 \\
\hline 17 & 26.62 & 2069 & 0.06 & Methyl20-methyl-docosanoate & $\mathrm{C} 24 \mathrm{H} 48 \mathrm{O} 2$ & 368 & 2510 \\
\hline 18 & 27.16 & 6757 & 0.19 & Tetracosanoic acid, methylester & $\mathrm{C} 25 \mathrm{H} 50 \mathrm{O} 2$ & 382 & 2674 \\
\hline 19 & 27.242 & 675771 & & Terephthalic acid, di(2-ethylhexyl)ester & $\mathrm{C} 24 \mathrm{H} 38 \mathrm{O} 4$ & 390 & 2704 \\
\hline & & 3652550 & 100.00 & & & & \\
\hline
\end{tabular}

Table 3: The total saturated and unsaturated Fatty acid content unsaturated/saturated fatty acid ratio identified in Cactus Opuntia dillenii seed-oil.

Cactus Opuntia dillenii
Total major saturated FA $22.63 \%$
Total major unsaturated FA $72.9 \%$
Unsaturated/Saturated FA ratio $3.22 \%$ higher amounts of total saturated fatty acids $22.63 \%$, with unsaturated/ saturated major fatty acid ratio of 3.22 (Table 3). Moreover, in another study, it has been reported that linolenic acid constituted the main fatty acid (66.56\%), followed by palmitic acid (19.78\%), stearic acid $(9.01 \%)$, and linoleic acid (2.65\%) in Cactus Opuntia dillenii. ${ }^{33}$ The profile of fatty acid extracted from different Cactus Opuntia dillenii varieties grown in different regions worldwide is more likely due to the interaction between genetics and different environment which impact very much the fatty acid content of different oil seed plants.

In the fatty acid biosynthesis pathway, the oleic acid content, which is synthesized from stearic acid by the Stearoyl-Acyl Carrier Protein Desaturase (SACPD) and at the same time is considered as the precursor of the linoleic acid (by the Fatty acid desaturases (FAD2), was very low in Cactus Opuntia dillenii seeds. This could be explained by the high activity of the FAD2 enzyme in converting most of the synthesized oleic acid to linoleic acid. It has been shown that both $S A C P D$ and FAD2 activity (down-regulation or up-regulation) have a major effect on controlling levels of stearic and oleic acids in oil seed plants including soybeans (due to induced and/or natural occurring mutations) and olives. ${ }^{38-40}$ In fact, duplicated oleaster FAD2 genes were found to be regulated by an siRNA derived from a transposable element-rich region responsible for suppressing levels of FAD2 gene expression. Neofunctionalization of $S A C P D$ gene family members has been shown to increase expression of $S A C P D 2,3,5$, and 7 resulting in an increased desaturation of stearic acid. ${ }^{41}$ Thus, the accumulation of exceptionally high levels of linoleic acid in in Cactus Opuntia dillenii seeds may be likely be explained by an increase/decrease of SACPD/ FAD2 expression.

Linoleic acid is an essential fatty acid and is the precursor of the very long polyunsaturated fatty acids like the arachidonic (ARA) that are beneficial for human health. ARA (20:4) is present in phospholipids of membranes of the body's cells, abundant in the brain, and liver. ${ }^{42}$
Leguminous plants like soybeans present also higher amounts of polyunsaturated linoleic acid (55\%), followed by oleic acid (20\%), while the saturated fatty acids like palmitic and stearic acids present $10 \%$ and 3\%, respectively. ${ }^{36}$ Stearic acid content in Cactus oil (7.51\%) was much higher than in soybeans, considered the largest source of animal protein feed and the second largest source of vegetable oil in the world. Stearic acid presents neutral effect on the concentration of blood serum LDL cholesterol and does not exhibit cholesterolemic effects on human health. Many efforts have been made by the soybean community and industry to increase the stearic acid content in soybeans by EMS mutagenesis and mutational breeding. ${ }^{43}$ However, all developing soybean lines with high stearic acid content (10 to $20 \%$ ) presented poor agronomic performance because the non-healthy nodules. ${ }^{43}$ Therefore, extracted natural cactus seed-oil present additional value for human health benefits compared with soybeans.

The fatty acid contents obtained in this study were quite similar to those found in the Opuntia ficus-indica seed-oil studied by Ozcan and $\mathrm{Al}$ Juhaimi. ${ }^{43}$ In fact, linoleic acid and palmitic acid contents were $67 \%$ and $16 \%$, respectively. The environmental conditions such as heat and humidity, in addition the fruit maturity conditions may explain the observed differences in the oil concentrations. ${ }^{44}$

\section{Sensory evaluation of cake}

The sensory evaluation results are shown in Table 4. The five sensory indexes of 5, 10, and 15\% Cactus seed-oil treatment was evaluated and compared between different treated samples and the control sample. The obtained data showed that all the five sensory of 5\% Cactus seedoil treatment samples had a significant difference when compared to the control. However, no significant difference $(\mathrm{p}>0.05)$ in the two sensory indices (Texture, Taste) of cakes prepared with Opuntia dillenii seed-oil was found between $5 \%$ and $10 \%$ of Cactus seed-oil treatment samples. The two sensory indexes (Texture, Taste) of cakes prepared 
with Opuntia dillenii seed-oil using $15 \%$ of Cactus seed-oil treatment had significant differences $(\mathrm{p}<0.05)$ compared to $5 \%$ and $10 \%$ of Cactus seed-oil treatment samples. Similarly, significant difference $(p<0.05)$ regarding overall acceptability of cakes prepared with Opuntia dillenii seed-oil was found between $5 \%$ and $10 \%$ of Cactus seed-oil treatment samples. But there was no significant difference $(p>0.05)$ between $5 \%$ and $10 \%$ of Cactus seed-oil treatment samples regarding overall acceptability index. These results were in agreement with Hafez (2012) who showed the absence of any significant differences among the samples with and without marjoram powder substitution for the liking scores of crump color, texture, and overall acceptability.

Cactus Opuntia dillenii seeds contained higher amounts of healthy fatty acids. Moreover, polyunsaturated fatty acids may be natural source of edible oil and contribute to the reduction of both total and LDL cholesterol and significant decrease in HDL cholesterol. ${ }^{45}$ Opuntia dillenii seed-oil presents a higher proportion of polyunsaturated fatty acids (linoleic acid) compared to conventional edible vegetable oils such as olive oil, soy oil, corn oil, sesame oil, sunflower oil, and cotton oil. ${ }^{35}$ Fatty acids play a natural preventive role in cardiovascular diseases and in alleviation of some other health problems. ${ }^{46}$

\section{Peroxide value determination}

The peroxide value of treated cake (Figure 4 ) at $4{ }^{\circ} \mathrm{C}$ with $0.03,0.05$, $0.07,0.09$, and $0.11 \mathrm{mg} / 100 \mathrm{~g}$ of butter from Cactus seed-oil showed no significant differences among the samples. However, there was a significant difference between the samples and the control. The treated cake with BHT at concentration 0.02 exhibited lower peroxide values ranged from ( 0.67 to 1.5 ) milli-equivalents (meq) peroxide per $1 \mathrm{~kg}$ of oil throughout 15 days of storage time at $4^{\circ} \mathrm{C}$. In contrast, the treated cake with $0.11 \mathrm{mg} / 100 \mathrm{~g}$ of butter from Cactus seed-oil presented lower peroxide values ranged from ( 0.69 to 2.5 ) (meq) peroxide per $1 \mathrm{~kg}$ of oil among all treatments. There was no significant difference ( $p>0.05$ ) between BHT and the treatment of 0.11 (mg/100g of butter).
In addition, the statistical analysis showed that there was a significant difference $(\mathrm{p}<0.05)$ between the control sample and all treatments at the same conditions.

These results suggested that seed-oil was effective in suppressing the oxidation of cakes. The anti-oxidative effect may have contributed to the oxidative stability of cakes with addition of natural antioxidants when added. These added antioxidants prevent the lipid peroxides formation during storage and delay oxidation. This could be due to the slow permeation rate of antioxidant components into lipid layer of the cakes. One of the most important changes that may occur to food is lipid oxidation. Lipid oxidation lowers the quality and nutritional value of food. ${ }^{47}$ The susceptibility of lipids to oxidation is one of the major causes of oxidative stresses, resulting in the development of rancidity, unpleasant tastes and odors, as well as changes in color. ${ }^{48}$ The concentration and effectiveness of these oils may vary among cultivars or varieties, crop environmental factors (i.e. light, temperature, and type of soil nutrients), or methods and solvents used for their extraction. ${ }^{49}$ Fruit seed-oils are of great interest because they present high degree of unsaturation and with antioxidant radical scavenging properties..$^{50}$ The oil from plants can be potentially used by the food industry for the manufacturing of "natural" or "green" safe foods and for extend shelf-life. ${ }^{51,52}$ The peroxide value is of the order of 1.43 for Opuntia ficus indica oil from cold pressure extraction, and 1.84 for hexane extraction. These peroxides index values are less than 10 meq $\mathrm{O} 2 / \mathrm{kg}$ oil which characterize most conventional oils. ${ }^{53,54}$ Indeed, lower peroxide index values $10 \mathrm{mEq} \mathrm{O} 2 / \mathrm{kg}$ oil is generally regarded as indicating an acceptable level of oxidation. ${ }^{6,41}$

\section{CONCLUSION}

Cactus fruit seeds are rich in minerals, with a predominance of calcium, phosphorus and potassium at 280.81, 243.90, and $181.96 \mathrm{mg} / 100 \mathrm{~g}$ respectively. Opuntia dillenii seed-oil was found to contain highest unsaturated fatty acid levels. In fact, linoleic acid presented $72.9 \%$

Table 4: Sensory evaluation of cakes prepared with Opuntia dillenii seedoil replacement of cake butter at $(5,10,15) \%$ of Cactus seed-oil.

\begin{tabular}{ccccc}
\hline Parameters & Control & $5 \%$ & $10 \%$ & $15 \%$ \\
\hline Color & $8.79 \pm 1.0^{\mathrm{a}}$ & $8.04 \pm 0.30^{\mathrm{b}}$ & $8.63 \pm 0.70^{\mathrm{c}}$ & $8.89 \pm 0.20^{\mathrm{c}}$ \\
Texture & $8.43 \pm 1.0^{\mathrm{a}}$ & $7.20 \pm 1.80^{\mathrm{b}}$ & $7.12 \pm 2.60^{\mathrm{b}}$ & $8.01 \pm 0.86^{\mathrm{c}}$ \\
Taste & $8.01 \pm 1.30^{\mathrm{a}}$ & $6.23 \pm 2.00^{\mathrm{b}}$ & $6.11 \pm 1.40^{\mathrm{b}}$ & $7.01 \pm 0.80^{\mathrm{c}}$ \\
Odor & $8.30 \pm 2.0^{\mathrm{a}}$ & $7.01 \pm 0.81^{\mathrm{b}}$ & $6.02 \pm 0.85^{\mathrm{c}}$ & $5.21 \pm 0.78^{\mathrm{d}}$ \\
Overall & & & & \\
Acceptability & $8.08 \pm 0.21^{\mathrm{a}}$ & $7.60 \pm 1.68^{\mathrm{b}}$ & $7.53 \pm 1.80^{\mathrm{c}}$ & $7.50 \pm 1.87^{\mathrm{c}}$ \\
\hline
\end{tabular}

* Means within each raw with the same superscript letter $(a, b, c)$ are not significantly different.

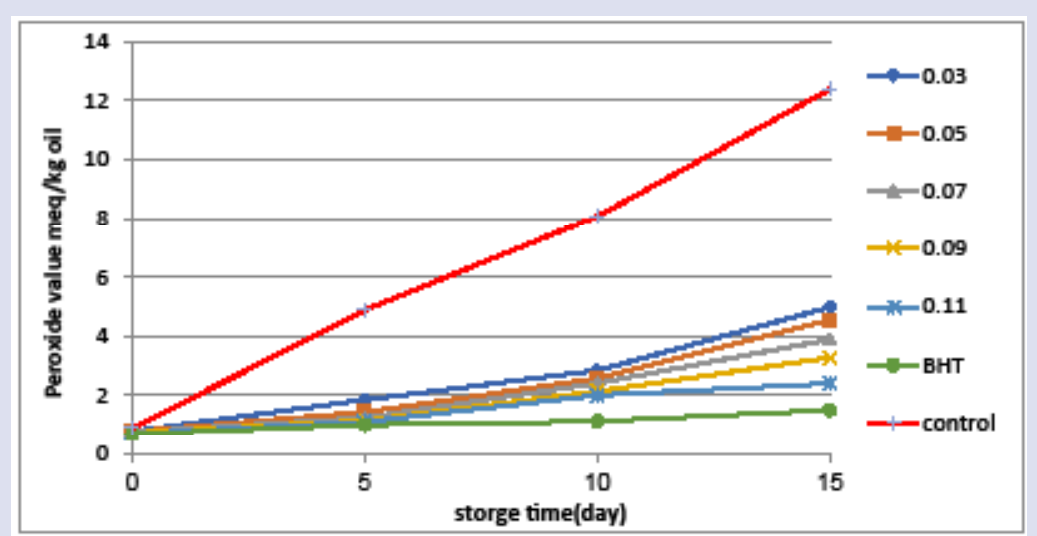

Figure 4. Peroxide value of treated cake with $0.03,0.05,0.07,0.09$, and $0.11(\mathrm{mg} / 100 \mathrm{~g}$ of butter) of Cactus seed-oil during 15 days storage. 
while saturated fatty acids presented $15.12 \%$ (palmitic acid) and $7.51 \%$ (stearic acid) (22.63 total saturated fatty acids), much higher than the total of saturated fatty acids $(\sim 14 \%)$ contained in soybean $[36,40,54]$. The high-saturated fatty acid composition $(>22 \%)$ and high linoleic acid contents $(72.9 \%)$ in Opuntia dillenii have positive impact to explore this plant as an alternative source for healthy oil by lowering cholesterol risks and for biodiesel production. The other essential oils were present at low percentage. The degree of sensory evaluation of the control cake and the substitution of butter with cactus seed-oil were very high in all qualitative elements. The treated cake with BHT at concentration 0.02 exhibited lower peroxide values ranged from (0.67 to 1.5$)$ milliequivalents (meq) peroxide per $1 \mathrm{~kg}$ of oil throughout 15 days of storage time at $4{ }^{\circ} \mathrm{C}$. In contrast, the treated cake with $0.11 \mathrm{mg} / 100 \mathrm{~g}$ of butter of Cactus seed-oil presented lower peroxide values ranged from 0.69 to 2.5 meq peroxide per $1 \mathrm{~kg}$ of oil among all treatments. These results further highlight the benefits of using Cactus seed-oil as a natural source for added nutritional value and use in industrial and/or pharmaceutical sectors.

\section{ACKNOWLEDGEMENTS}

We would like to thank the Food Science Department, College of Agriculture, University of Basrah for providing equipment and facilities.

\section{AUTHOR CONTRIBUTIONS}

A.JA. and S.N.A designed and planned the major experiments. A.A and N.L carried out and wrote-up the main manuscript text.

\section{CONFLICTS OF INTEREST}

The authors declare no conflicts of interest.

\section{REFERENCES}

1. Morales P, Ramírez-Moreno E, de Cortes Sanchez-Mata M, Carvalho AM, Ferreira IC. Nutritional and antioxidant properties of pulp and seeds of two xoconostle cultivars (Opuntia joconostle FAC Weber ex Diguet and Opuntia matudae Scheinvar) of high consumption in Mexico. Food Research International. 2012;46(1):279-285.

2. Altemimi A, Lakhssassi N, Baharlouei A, Watson D, Lightfoot D. Phytochemicals: Extraction, isolation, and identification of bioactive compounds from plant extracts. Plants. 2017a;6(4):42.

3. Park EH, Kahng JH, Lee $\mathrm{SH}$, Shin $\mathrm{KH}$. An anti-inflammatory principle from cactus. Fitoterapia. 2008;72(3):288-290.

4. Perfumi M, Tacconi R. Antihyperglycemic effect of fresh Opuntia dillenii fruit from Tenerife (Canary Islands). International journal of pharmacognosy. 1996;34(1):41-47.

5. Ennouri M, Evelyne B, Laurence M, Hamadi A. Fatty acid composition and rheological behaviour of prickly pear seed oils. Food Chemistry. 2005;93(3):431437.

6. Altemimi A. A study of the protective properties of Iraqi olive leaves against oxidation and pathogenic bacteria in food applications. Antioxidants. 2017;6(2): 34.

7. Murray RK, Granner DK, Mayes PA, Rodwell VW. Harper's Biochemistry, 25th Edition, McGraw-Hill, Health Profession Division, USA.

8. Ghazi Z, Ramdani M, Tahri M, Rmili R, Elmsellem H, El Mahi B, et al. Chemical composition and antioxidant activity of seeds oils and fruit juice of Opuntia Ficus Indica and Opuntia dillenii from Morocco. Journal of Materials and Environmental Science. 2015;6(8): 2338-2345.

9. Ghazi Z, Ramdani M, Fauconnier ML, El Mahi B, Cheikh R. Fatty acids Sterols and Vitamin E composition of seed oil of Opuntia Ficus Indica and Opuntia dillenii from Morocco. Journal of Materials and Environmental Science. 2013;5(6):967-972

10. Taoufik F, Zine S, El Hadek M, Idrissi Hassani LM, Gharby S, Harhar H, et al. Oil content and main constituents of cactus seed oils Opuntia Ficus Indica of different origin in Morocco. Mediterranean Journal of Nutrition and Metabolism. 2015;8(2):85-92.

11. Ghasemzadeh A, Ghasemzadeh N. Flavonoids and phenolic acids: Role and biochemical activity in plants and human. Journal of medicinal plants research. 2011;5(31):6697-6703.

12. Gharby $\mathrm{S}$, Harhar $\mathrm{H}$, Roudani A, Chafchaouni I, Charrouf Z. Stability oxidative from cosmetic and alimentary argan oil of thermal treatments. Int J Pharm Sci Invention. 2013;2(5):41-46.
13. Tharshini G, Sangwan $V$, Suman. Organoleptic and chemical characteristics of soybean and pomegranate peel powder supplemented cakes, Journal of Pharmacognosy and Phytochemistry. 2018;7(2):35-39.

14. Altemimi A, Lakhssassi N, Abu-Ghazaleh A, Lightfoot DA. Evaluation of the antimicrobial activities of ultrasonicated spinach leaf extracts using rapd markers and electron microscopy. Archives of microbiology. 2017b;119(10): 1417-1429.

15. Ebdon L, Fisher AS, Hill SJ. An introduction to analytical atomic spectrometry John Wiley \& Sons 1998.

16. Brand WW, Cuvelier HE, Berset $\mathrm{C}$. Use of a free radical method to evaluate antioxidant activity. Food Sci Technol. 1995;82:25-30.

17. American Association of Cereal Chemists. Approved Methods of A.A.C.C. Pp: 4, 13 and 61. Published by the American Association of Cereal Chemists.Inc., St Paul, Minnesota. USA, 1996

18. Eddy EO, Ukpong JA, Ebenso EE. Lipids Characterization and industria potentials of pumpkin seeds (Telfairia occidentalis) and cashew nuts (Anacardium occidentale). Journal of Chemistry. 2011;8(4):1986-1992.

19. Arrizon J, Calderón C, Sandoval G. Effect of different fermentation conditions on the kinetic parameters and production of volatile compounds during the elaboration of a prickly pear distilled beverage. Journal of Industrial Microbiology and Biotechnology. 2006;33(11): 921-928.

20. Saenz C. Processing technologies: an alternative for cactus pear (Opuntia spp.) fruits and cladodes. Journal of Arid Environments. 2000;46(3):209-225.

21. HabibiY, Heux L, Mahrouz M, Vignon MR. Morphological and structural study of seed pericarp of Opuntia ficus-indica prickly pear fruits. Carbohydrate Polymers. 2008; $72(1): 102-112$.

22. Cardador-Martínez A, Jiménez-Martínez C, Sandoval G. Revalorization of cactus pear (Opuntia spp.) wastes as a source of antioxidants. Food Science and Technology. 2011;31(3):782-788

23. Stintzing FC, Schieber A, Carle R. Evaluation of colour properties and chemical quality parameters of cactus juices. European Food Research and Technology. 2003;2016(4):303-311.

24. Labuschagne MT, Hugo A. Oil content and fatty acid composition of cactus pear seed compared with cotton and grape seed. Journal of food biochemistry. 2010;34(1):93-100

25. Chang SF, Hsieh CL, Yen GC. The protective effect of Opuntia dillenii Haw fruit against low-density lipoprotein peroxidation and its active compounds. Food chemistry. 2008;106(2):569-575

26. Salvo F, Galati EM, Lo Curto S, Tripodo MM. Study on the chemical characterization of lipid composition of Opuntia ficus-indica L. seed oil. Rivista Italiana delle Sostanze Grasse. 2002;79(11):395-398.

27. Matthäus B, Özcan MM. Habitat effects on yield, fatty acid composition and tocopherol contents of prickly pear (Opuntia ficus-indica L.) seed oils. Scientia Horticulturae. 2018;131:95-98.

28. Gharby S, Harhar H, Guillaume D, Haddad A, Matthaaus B, Charrouf Z. Oxidative stability of edible argan oil: A two-year study. LWT Food Sci Technol. 2011;44:18.

29. Koubaa M, Mhemdi H, Barba FJ, Angelotti A, Bouaziz F, Chaabouni SE, et al. Seed oil extraction from red prickly pear using hexane and supercritical $\mathrm{CO}_{2}$ : Assessment of phenolic compound composition, antioxidant and antibacterial activities. Journal of the Science of Food \& Agriculture. 2017;97:613-620.

30. Tesoriere L, Butera SD, Pintaudi AM, Allegra M, Livrea MA. J Clin Nutr 2014;80:391-395

31. Zine S, Gharby S, El Hadek M. Physicochemical characterization of opuntia ficus-indica seed oil from morocco. Biosci Biotechnol Res Asia. 2013;10(1):1-7.

32. Filip S, Hribar J, Vidrih R. Influence of natural antioxidants on the formation of trans-fatty-acid isomers during heat treatment of sunflower oil. European journal of lipid science and technology. 2011;113(2):224-230.

33. Soel SM, Choi OS, Bang MH, Park JHY, Kim WK. Influence of conjugated linoleic acid isomers on the metastasis of colon cancer cells in vitro and in vivo. The Journal of nutritional biochemistry. 2007;18(10):650-657.

34. Astiasaran I, Martinez AJ. Alimentos: Composiciony Propiedades/ICOAR Astiasaran (No. TX531. A45 2000)

35. Mailer RJ. The natural chemistry of Australian extra virgin olive oil. Rural Research and Development Corporation. 2016

36. Lakhssassi N, Zhou Z, Liu S, Colantonio V, AbuGhazaleh A, Meksem K. Characterization of the FAD2 gene family in soybean reveals the limitations of gel-based TILLING in genes with high copy number. Front Plant Sci. 2017;13(8):324.

37. Chougui N, Tamendjari A, Hamidj W, Hallal S, Barras A, Richard T, et al. Oil composition and characterisation of phenolic compounds of Opuntia ficusindica seeds. Food chemistry. 2013;139(1-4):796-803.

38. Lakhssassi N. Stearoyl-acyl carrier protein desaturase mutations uncover an impact of stearic acid in leaf and nodule structure. Plant physiology $2017 a$. 
39. Anderson J, Lakhssassi N, Kantartzi SK, Meksem K. Nonhypothesis analysis of a mutagenic soybean (Glycine max [L.]) Population for Protein and Fatty-Acid composition. J Am Oil Chem Soc. 2018.

40. Unver T, Wu Z, Sterck L, Turktas M, Lohaus R, Li Z, et al. Genome of wild olive and the evolution of oil biosynthesis. Proceedings of the National Academy of Sciences. 2017; 114(44):E9413-E9422.

41. Yong OY, Salimon J. Characteristics of Elateriospermum tapos seed oil as a new source of oilseed. Industrial Crops and Products. 2006;24(2):146-151.

42. Keys A, Anderson JT, Grande F. Prediction of serum-cholesterol responses of man to changes in fats in the diet. Lancet. 1957;273:959-966.

43. Özcan MM, Al Juhaimi FY. Nutritive value and chemical composition of prickly pear seeds (Opuntia ficus indica L.) growing in Turkey. International journal of food sciences and nutrition. 2011:62(5):533-536.

44. Coşkuner YN, Tekin A. Monitoring of seed composition of prickly pear (Opuntia ficus-indica $L$ ) fruits during maturation period. Journal of the Science of Food and Agriculture. 2003;83(8):846-849

45. Ajayi OB, Ajayi DD. Effect of oilseed diets on plasma lipid profile in albino rats. Pakistan Journal of Nutrition. 2009;8(2):116-118.

46. Farerni CA. Haematological parameters and enzyme studies in trypanosoma brucei-infected rats rearecl on nigella sativa oil-based diet. 2011.
47. Suja KP, Jayalekshmy A, Arumughan C. Antioxidant activity of sesame cake extract. Food chemistry. 2005;91(2):213-219.

48. Pezzuto JM, Park EJ. Autoxidation and antioxidants. Encyclopedia of pharmaceuticals technology. 2002;1:97-113.

49. Ramírez-Moreno E, Cariño-Cortés R, Cruz-Cansino NDS, Delgado-Olivares L, Ariza-Ortega JA, Montañez-Izquierdo VY, et al. Antioxidant and antimicrobial properties of cactus pear (Opuntia) seed oils. Journal of Food Quality. 2017.

50. Singh S, Das SS, Singh G, Schuff C, de Lampasona MP, Catalán CA Composition, in vitro antioxidant and antimicrobial activities of essential oil and oleoresins obtained from black cumin seeds (Nigella sativa L.). BioMed research international. 2014.

51. Tajkarimi MM, Ibrahim SA, Cliver DO. Antimicrobial herb and spice compounds in food. Food control. 2012;21(9):1199-1218.

52. Solórzano-Santos F, Miranda-Novales MG. Essential oils from aromatic herbs as antimicrobial agents. Current opinion in biotechnology. 2012;23(2):136-141.

53. FAOMHO Codex Alimentarius Commission, Codex Alimentarius Commission \& Joint FAOMHO Food Standards Programme. (2001). Codex alimentarius: fats, oils and related products (Vol. 8).

\section{GRAPHICAL ABSTRACT}

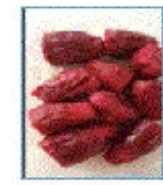

Caclus liui.

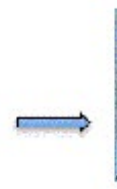

diy seed

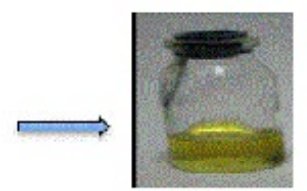

seedul

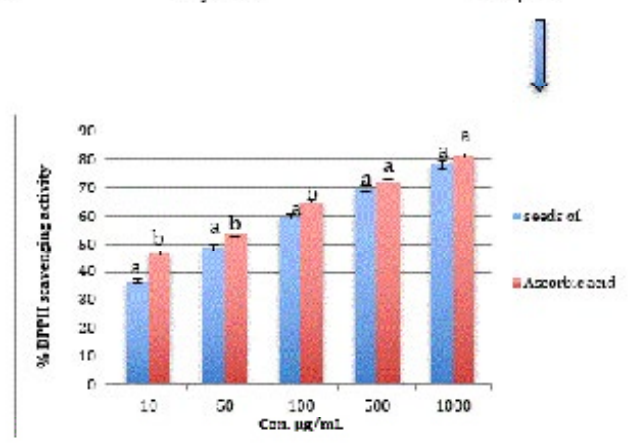

\section{ABOUT AUTHORS}

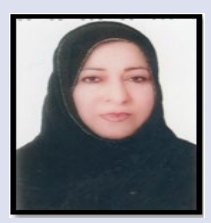

Dr. Alya Jameel Ali Alsaad a lecturer at Department of Food Science, Faculty of College of Agriculture, University of Basrah, Iraq. She has experience in the area of food chemistry and natural products.

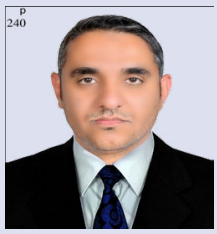

Dr.Ammar Altemimi worked as Lecturer (2009-present) in Department of foodscience and Biotechnology, University of Basrah, Iraq. He is now the chair of food science department, college of Agriculture, University of Basrah. He taught biochemistry and biotechnology for undergraduate, food chemistry, dairy products. Developing academic programs, monitor students educational progress, train and motivate other non-teaching staff; manage career counseling and other student service. He has published more than 11 papers in reputed journals such as Ultrsonic Sonochemistry Journal and Molecules Journal; and he has been serving as an editorial board member and reviewers of repute Journals. 


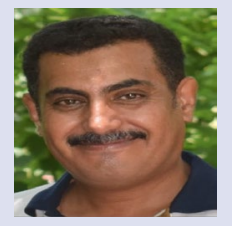

Dr. Salah N. Aziz a lecturer at Department of Food Science, College of Agriculture, University of Basrah, Iraq. He has experience in the area of molecular genetic and Biotechnology.

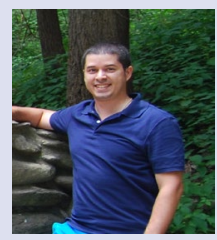

Dr. Naoufal Lakhssassi is currently an Associate Scientist at the Department of Plant Soil and Agricultural Systems, Agricultural College, Southern Illinois University Carbondale, USA. He holds a PhD in the field of Biochemistry and Molecular Biology from Malaga University, Spain, in the year 2011. He has been working on different biology projects related to microbiology, plant genetics, biochemistry, biotechnology, plant developmental biology, plant evolution, and bioinformatics. He served as an ad-hoc reviewer for several scientific journals including BMC Genomics, Plos1, Plant Cell Reports, and Crop Science, etc. $\mathrm{He}$ is serving on the editorial board of the Soil Science and Plant Health Journal, in addition to the Plant Science Journal. He handled several research projects during these years mainly working with Arabidopsis thaliana, tomato, and soybean with a major focus on soybean disease resistance and seed composition using mutation screening. Dr. Naoufal Lakhssassi's research includes characterization of considerable lines with increased seed oleic and stearic acids content, high protein content, tocopherols, desirable carbohydrates, high yielding varieties, in addition to the characterization of several genes involved in seed germination, and plant development.

Cite this article: Ali Alsaad AJ, Altemimi AB, Aziz SN, Lakhssassi N. Extraction and Identification of Cactus Opuntia dillenii Seed Oil and its Added Value for Human Health Benefits. Pharmacog J. 2019;11(3):579-87. 